\title{
Reproductive timing and investment in relation to spring warming and advancing agricultural schedules
}

\author{
Julia Schroeder · Theunis Piersma • Niko M. Groen • Jos C. E. W. Hooijmeijer • \\ Rosemarie Kentie $\cdot$ Pedro M. Lourenço $\cdot$ Hans Schekkerman $\cdot$ Christiaan Both
}

Received: 19 April 2011 /Revised: 8 August 2011/Accepted: 11 August 2011/Published online: 3 September 2011

(C) The Author(s) 2011. This article is published with open access at Springerlink.com

\begin{abstract}
Advances in mowing schedules have led to early and rapid declines in the seasonal food availability for, and survival rates of, chicks of grassland-breeding waders. Concurrently, increased levels of soil fertilization may have improved food abundance for adults. These developments are assumed to have resulted in an advancement of laying during 1930-1976 in several meadowbird species, including Black-tailed Godwits. Despite an apparent selective advantage of early breeding, after 1976 Godwits stopped advancing their laying dates. We have analyzed the timing of breeding and reproductive investment in Dutch Black-tailed Godwits relative to recent changes in agricultural practices and climate during 1976-2007. Early and late spring temperatures and precipitation in March were used as indicators for the timing of fertilizer application and mowing, and also as qualitative
\end{abstract}

Communicated by F. Bairlein.

J. Schroeder · T. Piersma - N. M. Groen ·

J. C. E. W. Hooijmeijer · R. Kentie · P. M. Lourenço · C. Both Animal Ecology Group, Centre for Ecological and Evolutionary Studies (CEES), University of Groningen,

P.O. Box 11103, 9700 CC Groningen, The Netherlands

J. Schroeder ( $\square)$

Animal and Plant Sciences, Sheffield University,

Western Bank, Sheffield S10 2TN, UK

e-mail: julia.schroeder@gmail.com

T. Piersma

Department of Marine Ecology, Royal Netherlands Institute for Sea Research (NIOZ), P.O. Box 59, 1790 AB Den Burg, Texel, The Netherlands

H. Schekkerman

SOVON Dutch Centre for Field Ornithology,

Postbus 6521, 6503 GA Nijmegen, The Netherlands measures of relative food availability for adults and chicks. When precipitation was higher in March, Black-tailed Godwits laid earlier. Following warmer winters, the earliest females laid larger eggs, which hatched heavier chicks with a higher survival probability. We suggest that the positive effect of an increasing March precipitation on invertebrate abundance may be constrained by the current policy of rigid control of the water table. This policy prevents Godwits from further advancing laying dates, which would increase their chick's survival prospects under increasingly early mowing schedules. Policy-makers should, next to delaying mowing schedules, also consider reduced draining in early spring as a tool to help stop the population decline of the Black-tailed Godwit.

Keywords Black-tailed Godwit - Climate change . Agricultural change - Farmland birds - Reproductive investment $\cdot$ Seasonal reproductive decline

\section{Zusammenfassung}

Brutzeitpunkt und Reproduktion von Uferschnepfen in Bezug auf Veränderungen landschaftlicher Aktivitäten und Klimaerwärmung

Immer frühere Mahdzeitpunkte führen zu einer immer früheren und schnellen Verringerung der saisonalen Nahrungsverfügbarkeit, und damit auch einer starken Abnahme der Überlebenschancen von Wiesenvogelküken. Im Gegensatz dazu hat die zeitgleiche zunehmende Düngung von Grasland sehr wahrscheinlich die Nahrungsgrundlage für adulte Wiesenvögel verbessert. Dies hatte zur Folge dass gleich mehrere Arten von Wiesevögeln einschließlich der Uferschnepfe zwischen 1930 und 1976 ihre Eiablage immer früher tätigten. Überraschenderweise, und obwohl 
eine früherer Eiablagezeitpunkt anscheinend einen Selektionsvorteil verschafft, stellten Uferschnepfen das Verfrühen der Eiablage nach 1976 ein. Hier präsentieren wir eine Analyse des Zeitpunktes der Eiablage und der Investition in die Reproduktion von niederländischen Uferschnepfen vor dem Hintergrund der rezenten Veränderungen landwirtschaftlicher Aktivitäten und des Klimas im Zeitraum von 1976-2007. Wir verwenden die mittleren Temperaturen während des frühen und späten Frühjahres sowie die Niederschlagssumme im März als Indikatoren für respektive den Zeitpunkt der Düngung, der Mahd und als qualitatives Maß des relativen Nahrungsangebot für adulte Uferschnepfen und Jungtiere. In Jahren mit feuchterem März legten Uferschnepfen ihre Eier früher. Nach wärmeren Wintern legten frühe Weibchen größere Eier, aus welchen Kücken in besserer Kondition schlüpften, welche eine bessere Überlebenswahrscheinlichkeit hatten. Unsere Resultate suggerieren, dass der positive Effekt, den die Klimaänderung auf den Niederschlag im Frühjahr, und damit auch auf die Nahrungsverfügbarkeit für adulte Uferschnepfen hat, durch die starke Kontrolle des Grundwasserspiegels zunichte gemacht wird. Dies verhindert, dass Uferschnepfen früher legen können, was die Überlebenschancen der Kücken unter immer früheren Mahdterminen deutlich verringert.

\section{Introduction}

In seasonal habitats, the timing of reproduction is very important for the reproductive success of birds. Because offspring survival depends on food resources, parents are expected to time reproduction so that maximum offspring food requirements coincide with maximum food availability. Therefore, it can happen that females lay when food availability for themselves is still low, which affects their reproductive investment and their survival (Drent 2006). From a parental perspective, the optimal laying date is a trade-off between self-maintenance costs and fitness benefits for offspring (Daan and Tinbergen 1997). If the fitness prospects relative to season change due to long-term directional environmental change, birds could adjust either the laying date or their reproductive investment. However, if birds are constrained in adjusting the laying date, they may lay fewer eggs (Both and Visser 2005), or, if clutch size is invariant, smaller ones (Williams 2005).

Selection pressures on the timing of reproduction may vary between years due to environmental stochasticity, but also in response to directional changes. Accordingly, temperate bird species tend to show directional trends in laying dates associated with recent trends in spring warming (e.g. Both et al. 2004), because when phenology of lower trophic levels is affected by climate warming, matches between food requirements and availability can be achieved by earlier breeding (Both et al. 2009). However, resource phenology for parents during egg production may change at a different pace than the phenology of resources for offspring, which affects the trade-offs between adult survival and reproductive output (Both et al. 2006).

Climate change is not the only directional selection pressure on the timing of breeding. For farmland birds, such as grassland-breeding waders (meadowbirds), the most challenging pressures are advances in the timing and intensity of agricultural activities (Schekkerman et al. 2009; Pearce-Higgins and Gill 2010). In grasslands, the timing of fertilizer application and mowing has advanced over the years, and water drainage is the norm nowadays. These developments, the use of better and more fertilizers, and spring warming has led to earlier grass phenology and enhanced growth, allowing farmers to have more and earlier harvests per season (Kleijn et al. 2010).

The chick perspective

Mechanical mowing exerts strong selection pressure on ground-breeding meadowbirds by destroying nests and killing chicks (Schekkerman et al. 2009). Surviving chicks grow up in short grass where a severe drop in food availability further reduces their survival prospects (Schekkerman and Beintema 2007; Schekkerman et al. 2009). Drier summers due to climate change may have the same effect on insect availability, which is the major food source for chicks (Pearce-Higgins et al. 2009). Thus, whereas an acceleration of vegetation growth may advance the seasonal insect peak abundance and reduce foraging success for chicks born later in the season, the same acceleration of vegetation growth leads to earlier mowing dates and a decrease in available foraging habitat for chicks (Kleijn et al. 2010). We therefore expect that selection for early laying has increased over the last decades and that being born early is beneficial for chicks (Roodbergen and Klok 2008). The above factors have played an important role in the decrease in the number of breeding pairs in meadowbird populations throughout Europe (Chamberlain et al. 2000).

\section{The parent perspective}

Adult meadowbirds forage mainly on ground-dwelling invertebrates, such as earthworms. The combination of increased use of fertilizer and drier-and therefore warmer-soils early in spring positively affects belowground prey abundance (Edwards and Lofty 1982), favoring adult birds when they gather resources for egg laying after the spring migration. Food availability will affect female 
nutritional state, which in turn positively influences laying date and reproductive investment (Bolton et al. 1992), enabling females to initiate larger clutches at an earlier date (Nager 2006). Indeed, there is support for an advancement of laying date in five meadowbird species during 1940-1976, including the Black-tailed Godwits Limosa l. limosa, which advanced laying date by 2 weeks during this period concurrently with the increased use of fertilizer, which has been suggested to enhance food availability (Beintema et al. 1985).

Since 1976, agricultural practices have continued to intensify, with nitrogen loading of the Dutch grasslands increasing until the 1980 and declining thereafter. Fertilizing takes place ever earlier in the spring/late winter, and mowing dates have advanced. All of these practices have occurred concurrently with increases in local spring temperature and precipitation. The expectation is, therefore, that meadowbirds have continued to advance their timing of breeding. Indeed, between 1900 and at least 2003 Northern Lapwings (Vanellus vanellus) advanced their laying dates in correspondence with warmer springs and wetter winters (Both et al. 2005). Black-tailed Godwits did not advance their timing of breeding (Kleijn et al. 2010), and given the changes in ecological conditions, chicks now likely hatch too late. If Godwits are somehow constrained in advancing their laying date further, we expect them to make the best of a bad situation and change the seasonal reproductive investment by investing most at times when survival chances for offspring are the highest, but also when the egg-producing females have the most resources to invest.

The Dutch Black-tailed Godwit population, which makes up approximately $90 \%$ of the West European population, has plummeted by approximately $50 \%$ since the 1960s and is continuing to decline (Gill et al. 2007). This decreasing trend has been attributed to reduced reproductive output because adult survival has remained high (Roodbergen et al. 2008; Schroeder et al. 2010). Consequently, detailed information on the adaptive potential of Godwits to changes in climate and agriculture is urgently needed in order that a successful management program can be designed (Gill et al. 2007; Pearce-Higgins and Gill 2010).

Here, we present a dataset that supports the advance of laying dates in Black-tailed Godwits prior to 1975, as well as long-term data on laying date and reproductive investment of Dutch Godwits. We studied how the birds have adjusted hatchling mass in relation to the expected timing of the natural peaks in chick food availability. Predicted timing of mowing was used as a proxy for the realized peak in chick food availability. To unravel potential mechanisms and cues for when to breed and how much to invest to maximize reproductive success, we examined hatchling mass in relation to two correlates of adult food availability during the pre-breeding phase, namely, the timing of the first annual application of fertilizer to grasslands and the amount of precipitation in March. In view of the increasing practice of draining fields, which likely negatively influences soil invertebrate availability, we reviewed a 100 -year dataset of water tables. Conclusions are drawn on the potential of Black-tailed Godwits to benefit from climate change and advance laying to cope with advancing agricultural schedules.

\section{Materials and methods}

Black-tailed Godwits return to their Dutch breeding grounds between late February and early April. Females initiate nests from early April onwards. Replacement clutches after nest failure occur, but are rare after mid-May (Schekkerman and Müskens 2000). The precocial chicks hatch during May and June; their diet consists of insects from the grass canopy, which exhibit a seasonal abundance peak correlated with temperature and mowing date of the sward (Pearce-Higgins and Yalden 2004; Schekkerman and Beintema 2007).

Since the breeding habitat of the Black-tailed Godwit in The Netherlands is nearly always grassland managed for agricultural exploitation, Godwits are heavily influenced by agricultural activities, even in areas managed specifically for meadowbirds. From February onwards, depending on the weather, farmers apply fertilizers (either an organic nitrogen or manure) and mowing currently starts in April (Kleijn et al. 2010). A common conservation management tool is to postpone mowing until most eggs have hatched (Gill et al. 2007).

We present data from Haverschmidt (1963) on the date of the first arrival of Godwits and the date the first egg was found in Friesland, the province that harbors most breeding Godwits in The Netherlands.

For our analyses, we used four datasets collected during 1976-2007, comprising data on 3,309 hatchlings and hatching dates. Hatchlings were ringed in the nest on the day of hatching, and some of them were, mostly unsystematically, recaptured before fledging. The four datasets are (Table 1): (AB) during 1976-1985, data on 1,480 hatchlings and 49 recaptured chicks were collected nationwide (Beintema 1995); (NG) from 1984 to 1989, data on 966 hatchlings, 12 recaptured chicks, and egg dimensions from 265 nests were obtained in a nature reserve near Zaanstad $\left(52^{\circ} 31^{\prime} \mathrm{N}, 4^{\circ} 47^{\prime} \mathrm{E}\right)$ (Groen and Hemerik 2002); (HS) data on 99 hatchlings were collected near Baarn $\left(52^{\circ} 12^{\prime} \mathrm{N}, 5^{\circ} 19^{\prime} \mathrm{E}\right.$ ) from 1993 to 1995 (Schekkerman and Beintema 2007); (JS) from 2004 to 2007, data on 764 hatchlings, 43 recaptured chicks, and corresponding 207 
Table 1 Annual sample sizes of Black-tailed Godwit nests, eggs, chicks, and laying dates included in the present analysis, and the dataset from which the data were extracted

\begin{tabular}{|c|c|c|c|c|}
\hline Dataset & Year & $\begin{array}{l}\text { Nests with } \\
\text { chicks and } \\
\text { corresponding } \\
\text { egg volume }\end{array}$ & $\begin{array}{l}\text { Hatchlings } \\
\text { and laying } \\
\text { dates }\end{array}$ & Recaptures \\
\hline $\mathrm{AB}$ & 1976 & NA & 91 & 4 \\
\hline $\mathrm{AB}$ & 1977 & NA & 119 & 6 \\
\hline $\mathrm{AB}$ & 1978 & NA & 258 & 15 \\
\hline $\mathrm{AB}$ & 1979 & NA & 201 & 3 \\
\hline $\mathrm{AB}$ & 1980 & NA & 98 & NA \\
\hline $\mathrm{AB}$ & 1981 & NA & 132 & 9 \\
\hline $\mathrm{AB}$ & 1983 & NA & 54 & 2 \\
\hline $\mathrm{AB} / \mathrm{NG}$ & 1984 & $\mathrm{NA}$ & 385 & 8 \\
\hline $\mathrm{AB} / \mathrm{NG}$ & 1985 & 68 & 461 & 2 \\
\hline NG & 1986 & 65 & 222 & 8 \\
\hline NG & 1987 & 47 & 160 & NA \\
\hline NG & 1988 & 44 & 145 & 2 \\
\hline NG & 1989 & 41 & 120 & 2 \\
\hline HS & 1993 & NA & 49 & NA \\
\hline HS & 1994 & NA & 28 & NA \\
\hline HS & 1995 & $\mathrm{NA}$ & 22 & NA \\
\hline JS & 2004 & 32 & 86 & 8 \\
\hline JS & 2005 & 54 & 160 & 8 \\
\hline JS & 2006 & 39 & 154 & 2 \\
\hline JS & 2007 & 82 & 364 & 25 \\
\hline
\end{tabular}

$N A$ data not available

nests with egg dimensions were collected in southwest Friesland $\left(52^{\circ} 59^{\prime} \mathrm{N}, 5^{\circ} 24^{\prime} \mathrm{E}\right)$ (Schroeder et al. 2009).

The data included in dataset $(\mathrm{AB})$ were gathered unsystematically on several sites, while the data compiled in the other three datasets come from long-term nature reserves or areas with agri-environment schemes (AES) that are managed for meadowbirds. In (AB), areas with high godwit densities likely have provided most chicks since the avoidance of such sites seems unlikely. Recent AES aim to resemble such high-quality areas and, therefore, differences in area quality other than the studied parameters can likely be neglected for the purposes of our study.

Egg volume data were available for 1984-1989 (NG) and 2004-2007 (JS) and was calculated as length $\times$ width $^{2} \times 0.52$ (Schroeder et al. 2009). Godwits have an almost invariant clutch size of four. Consequently, females can invest differentially in clutches mainly by varying egg volume and timing of laying. Egg production is costly in birds (Williams 2005) and can affect female survival and future fecundity (Monaghan et al. 1998; Visser and Lessells 2001). Egg volume reflects female nutritional status at laying (Amat et al. 2001), and Godwits that are relatively heavy for their size lay larger eggs (Schroeder et al. 2009).
We calculated average egg volume per nest (only nests with four eggs) as an index of female reproductive investment.

Hatchling mass, for which a larger dataset is available, was used to test whether females adjust reproductive investment to environmental conditions. This is a reasonable approach because variation in hatchling mass is largely explained by egg volume, and heavier chicks are more likely to survive (this study). We tested for an association between hatchling mass and subsequent recapture during the chick period (binary) as a proxy for chick survival. Only recaptures of chicks older than 4 days were used because the mortality of godwit chicks decreases substantially after the first few days (Schekkerman et al. 2009). We only used years in which at least one chick older than 4 days was recaptured.

Reproductive success is related to laying date in Blacktailed Godwits, with earlier chicks surviving better (Roodbergen and Klok 2008). We therefore analyzed within- and between-year variation in laying date. Laying date was calculated by subtracting incubation duration from hatching date or, if hatching date was unknown, by estimating the incubation stage of the eggs (Schroeder et al. 2009).

We considered four proxies for the phenology of food abundance for chicks and for factors affecting food abundance for adults. Temperature-sums, the sum of all average daily temperatures for days with positive temperatures from the first of January onwards, are often used by farmers as indicators for the progress of plant phenology. We used temperature-sum data from the Royal Netherlands Meteorological Institute (KNMI) collected at De Bilt, central Netherlands, from 1901 to 2007. Average May temperature was used as a proxy to characterize the chick period, as temperature affects insect abundance and thereby the time that a natural peak in food availability can be expected (Pearce-Higgins and Yalden 2004) (proxy 1). A general predictor of when $50 \%$ of the grassland area is mown is when the temperature-sum reaches $890^{\circ} \mathrm{C}$ (Kleijn et al. 2010). Therefore, a temperature-sum of $890^{\circ} \mathrm{C}$ indicates a sharp decline in food availability for chicks due to the removal of the grass canopy layer, the main habitat for prey insects, by mowing (Schekkerman and Boele 2009) (proxy 2). The timing of soil fertilizing and wetness determine the vertical distribution and abundance of ground arthropods (Edwards and Lofty 1982), and both of these factors were used as qualitative indicators of the food situation before egg-laying: the date when farmers apply the first fertilizer dressing (temperature-sum $180^{\circ} \mathrm{C}$; Kruk et al. 1996), as a relative measure for the timing of food availability for foraging adults (proxy 3). We used precipitation during March, which influences soil wetness during the pre-laying period, because ground arthropods are more available in wetter than dry soils, as proxy 4 (Edwards and Lofty 1982).

We obtained data on the daily water table of the total drainage area of the province of Friesland for the last 
110 years, provided by Wetterskip Fryslân (Claassen 2008). These data could not be used in the correlation analyses because not all of our study areas are located in Friesland. However, assuming that trends in these data are representative for the situation in the whole country, possible implications are discussed.

\section{Statistical analyses}

To show that hatchling mass conveys the same information as egg volume, we used a linear mixed model (LMM) explaining average hatchling mass. Year was modeled as a random factor to account for variation in annual sample sizes, and average egg volume per nest and data-subset were modeled as explanatory variables. Averages per nest were used due to the lack of data linking individual eggs with hatchlings. Data were available for 472 nests (Table 1).

To examine the association between individual hatchling mass and chick survival, we modeled the variable 'recaptured-not recaptured' in a generalized logistic mixed model (GLMM) with a logit-link function. Laying date was modeled together with hatchling mass as covariates. Year was modeled as a random effect on the intercept. Brood was not included as a random effect in any of our analyses due to the lack of information on brood of origin for a large part of our dataset.

Median annual laying date was modeled in a linear model (LM), with all environmental variables and year as covariates, to examine the change of laying date over time.

To study the relationship between hatchling mass and laying date over time, we applied a LMM explaining individual hatchling mass with individual laying date, using year as the continuous variable, since we were interested in a change over time, the interaction of both, and the environmental covariates. We additionally modeled year as random effect to account for sample size differences between years.

A change in the effect of date on chick mass over the years could be caused by changes over the entire season or by changes in either the earlier or later part of the season. Using LMs, we tested for associations between environmental variables and the average hatchling mass of clutches from the $10 \%$ earliest and latest laying dates of each year. This analysis also controlled for possible bias introduced by replacement clutches.

The variance inflation factor (VIC) was used to determine collinearity between environmental covariates-if deemed necessary. We removed covariates with $\mathrm{VIC}>3$ (Zuur et al. 2010). R.2.7.1 statistical software (R Development Core Team 2009) was used, with the lmer() function for fitting $(\mathrm{G}) \mathrm{LMMs}$ and the $\operatorname{lm}()$ function for LMs, using backwards stepwise deletion of non-significant effects. We used the function pvals.fnc() to calculate
$P$ values and confidence intervals for the fixed effects of LMMs, using MCMC estimation (Baayen 2007).

\section{Results}

Larger eggs hatched larger chicks (Fig. 1). The best model explained hatching mass with egg volume only [LMM: $\beta_{\mathrm{EV}}=5.30,95 \%$ confidence interval (CI) 4.85-5.73, $\left.P<0.001, n=472, R^{2}=0.54\right]$; neither dataset nor its interaction with egg volume remained in this model $(P>0.28)$. Recaptured chicks were heavier and earlier than chicks that were not recaptured (GLMM: $\beta_{\text {mass }}=0.09,95 \%$ CI $0.01-0.17, z=2.28, P=0.02 ; \beta_{\text {hatching date }}=0.04,95 \%$ CI -0.01 to $-0.06, z=-2.66, P=0.008, n=2,903)$.

The date the first godwit egg was found in the province of Friesland advanced from 1930 to 1962 , as did the date of the first godwit arrival (Fig. 2 ; first egg: $F_{1,29}=11.83 ; R^{2}=0.29$; $P=0.002$; arrival: $\left.F_{1,27}=9.17 ; R^{2}=0.25 ; P=0.005\right)$.

There was no change in the three environmental variables for temperature (Fig. 3a-c) up to approximately 1975, after which they reflect a warming trend in the winter and spring climates. From 1950 onwards, there was an increase in March precipitation (Fig. 3d). Prior to 1976, the temperature-sum $180^{\circ} \mathrm{C}$ and average May temperatures were not correlated with each other $(r=0.19, P=0.11)$, indicating that conditions at the end of winter could not be used as a cue for conditions later in spring to adjust reproductive timing and investment. In addition, precipitation during March was not correlated with May temperatures $(P=0.97)$ and could not be used as a timing cue for the food peak of chicks. After 1976, the temperature-sum

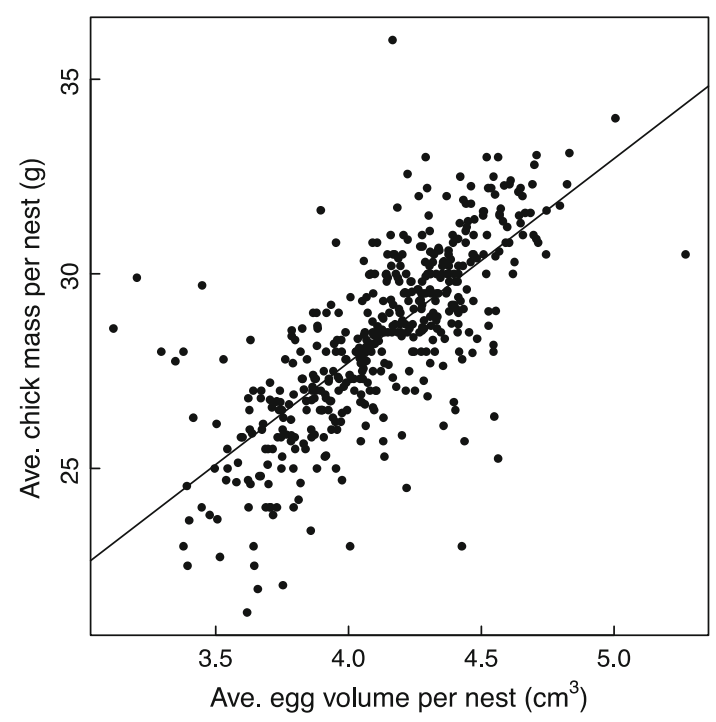

Fig. 1 The relationship between average egg volume per nest and average chick mass in Black-tailed Godwits breeding in The Netherlands between 1985 and 2007 (see Table 1) 




Fig. 2 The advance in the time (days from 1 January, Julian dates) the first Black-tailed Godwit egg of the season was found (filled circles) and the first Black-tailed Godwit arrived (open circles) in the province of Friesland, The Netherlands, from 1930 to 1962. Data were retrieved from Haverschmidt (1963)

$180^{\circ} \mathrm{C}$ was positively correlated with May temperatures $(r=-0.41, P=0.02)$, but precipitation during March was not correlated with any other environmental variable (all correlations $P>0.10$ ),

Even though the amount of precipitation in March increased (Fig. 3d), by 1960 the groundwater table in Friesland had been lowered by about half a meter compared with values before 1950, and variance in the water tables decreased considerably (Fig. 3e). The installation of drainage tubes to grassland beginning in the early 1980 s was accompanied by a disappearance of shallow water finger dykes and land smoothing, leading to the rapid dehydration of the top soil layer after heavy rains, but also to bone-hard top soils in periods of drought (personal observation).

Laying date has not advanced since 1976 (Fig. 4; $F_{1,18}=0.06, P=0.81$ ), although it did so prior to 1976 [Fig. 1, and data by Beintema et al. (1985) included in Fig. 4]. To exclude that since 1976 a hypothetical increase of second clutches obscured a possible trend, and that the decrease in population size concealed a possible advance in our data (Tryjanowski and Sparks 2001), we tested for only the mean of the earliest 10,20 , and $30 \%$ of clutches in a year and the mean between 20 and $80 \%$ of the laying date distribution each year. No advancement of laying date was found for any of these subsets (all $P>0.77$ ).

After the stepwise deletion of terms of a LM explaining annual laying dates with environmental covariates, only March precipitation remained in the model $\left(F_{1,26}=4.79, R^{2}=0.12\right.$, $P=0.04)$. Godwits laid earlier in years with higher precipitation in March. The interaction between year and March precipitation was not significant (removed terms $P>0.25$ ).

The seasonal decline of hatchling mass became stronger over the years and with an earlier temperature-sum of
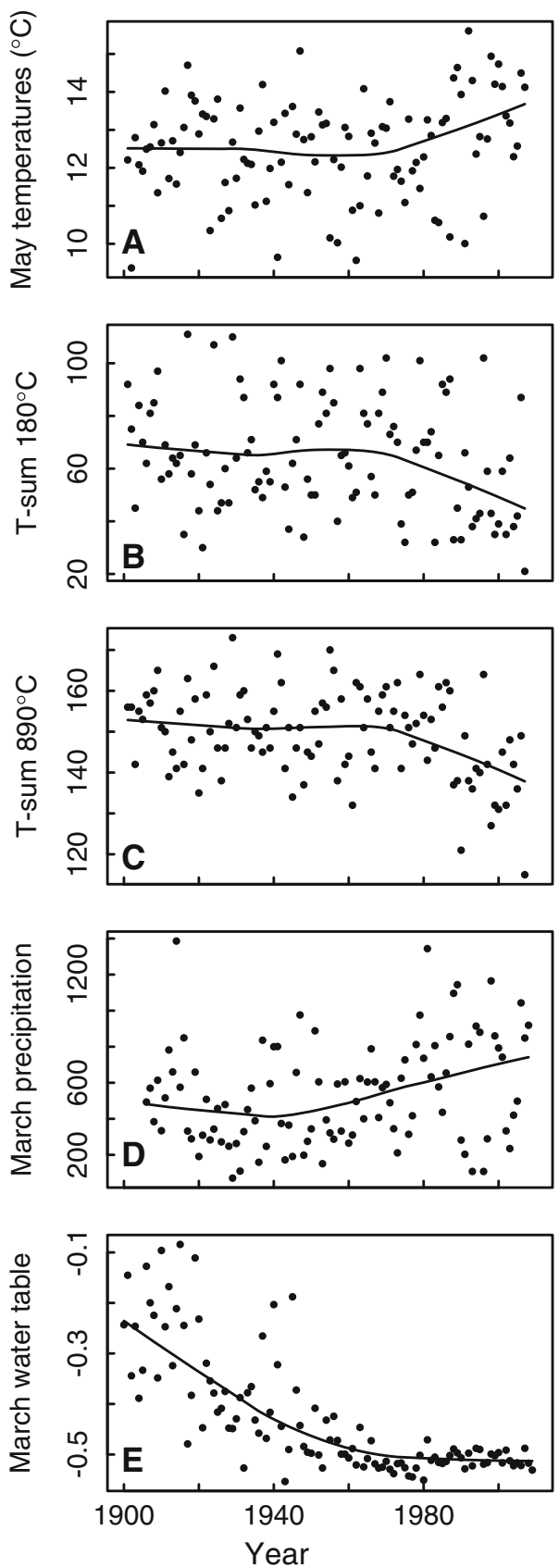

Fig. 3 Average May temperature in degrees Celsius (a), the number of days (from 1 January) when the temperature-sum of $180^{\circ} \mathrm{C}(T$-sum 180 , b) and $890^{\circ} \mathrm{C}$ (T-sum 890 , c) was reached, and the average March precipitation (ml) (d), during 1901-2008 at De Bilt, The Netherlands. Lines Locally weighted regression scatter-plot smoothing (LOWESS, $f=1$ ) to enhance visual perception. e Development of average monthly water tables (m a.s.l.) in March of the drainage basin in the province of Friesland, The Netherlands, from 1900 to 2009. Data courtesy of the Friesland Water Authority (Wetterskip Fryslân)

$180^{\circ} \mathrm{C}$ (Table 2). Due to strong collinearity (VIC $>3$ ), we excluded the temperature-sum $890^{\circ} \mathrm{C}$ and its interaction with laying date from this analysis; however, these terms were tested stepwise, and neither was significant when 


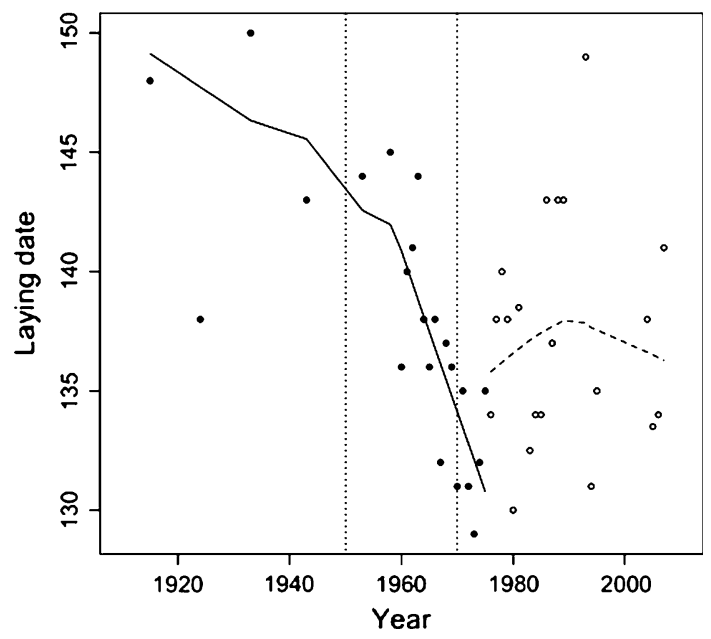

Fig. 4 Median annual laying dates of Dutch Black-tailed Godwits (days from 1 January). Black dots Data retrieved from Beintema et al. (1985), open circles data from this study. Lines Locally weighted regression scatter-plot smoothing. The leftmost dotted vertical line Approximate start of the increase of March precipitation, rightmost dotted vertical line approximate time when water tables continued to stay extremely low and with little variance (see Fig. 3)

included in the model (all $P>0.57$ ). May temperature and its interaction with laying date were removed from the most parsimonious model, as was March precipitation and its interaction with laying date (all $P>0.30$ ). Considering the period since 1976, we found that the effect of laying date on hatchling mass was initially positive. However, the earlier the temperature-sum $180^{\circ} \mathrm{C}$ occurred, the stronger the negative effect of laying date on hatchling mass became (Table 2, Fig. 5a). Over the years and with increasingly early temperature-sum $180^{\circ} \mathrm{C}$ date, early born chicks have became heavier and later born chicks lighter. This is consistent with the lack of change in annual average hatchling mass, or in its annual variance (hatchling mass,
$F_{1,18}=1.74, \quad P=0.20 ;$ variance of hatchling mass: $\left.F_{1,18}=0.19, P=0.67\right)$.

To develop a better understanding of why birds have been laying larger eggs early in more recent years and in years with warmer weather and smaller eggs later in colder years, we examined patterns between environmental variables and the annual mean mass of either early or late hatchlings. We employed two LMs to (1) correlate the annual average hatchling mass of the $10 \%$ earliest $(n=307)$ and (2) $10 \%$ latest born chicks per year $(n=150)$, respectively, with environmental covariates. In the best model with the earliest chicks (LM 1), only the temperature-sum $180^{\circ} \mathrm{C}$ remained, indicating that early hatchlings were heavier in springs after relatively warm winters [Fig. $5 \mathrm{~b} ; F_{1,18}=7.55, P=0.01$, $\beta_{\mathrm{t} \text {-sum 180 }}=-0.04 \pm 0.02$ (standard error)]; all other variables were removed from the final model (temperature-sum $890^{\circ} \mathrm{C}: P=0.10$, all other $P>0.45$ ). In the best model with the latest chicks (LM 2), only the temperature-sum $890^{\circ} \mathrm{C}$ remained, indicating that late hatchlings were lighter in years with warmer weather (Fig. 5c; $F_{1,18}=8.08$, $\left.P=0.01 ; \quad \beta_{\mathrm{t} \text {-sum890 }}=0.05 \pm 0.02\right) ;$ all other variables were removed from the final model (temperature-sum $180^{\circ} \mathrm{C}: P=0.10$, all other $P>0.31$ ). Neither May temperatures nor precipitation in March explained the change in hatchling mass over the season.

\section{Discussion}

During the last 30 years Black-tailed Godwits have experienced strong directional changes in the characteristics of agricultural grassland, their main breeding habitat in The Netherlands. Increasingly warm winters and springs, improved fertilization techniques, and increasingly effective drainage regimes have enabled agricultural schedules to be considerably advanced (Kleijn et al. 2010). This

Table 2 Results of a linear mixed model ${ }^{\mathrm{a}}$ explaining mass at hatching (standardized to the mean) of Black-tailed Godwits between 1976 and 2008 in The Netherlands

\begin{tabular}{lccr}
\hline Covariate & Estimate & 95\% Confidence interval & $P$ \\
\hline Laying date & 2.38 & -0.03 to 4.77 & 0.06 \\
Year & 0.02 & -0.08 to 0.14 & 0.66 \\
t180 & -0.04 & -0.06 to -0.01 & 0.006 \\
Laying date $\times$ year & -0.0012 & -0.002 to -0.001 & 0.048 \\
Laying date $\times$ t180 & 0.0008 & 0.0004 to 0.001 & $<0.001$ \\
NG & 0.11 & -0.22 to 0.47 & 0.53 \\
HS & 0.19 & -1.42 to 1.76 & 0.80 \\
JS & 0.53 & -1.96 to 3.01 & 0.66
\end{tabular}

T180, Temperature-sum $180^{\circ} \mathrm{C}$. NG, HS, JS, Different datasets (see "Materials and methods" for more details)

a Temperature-sum $180^{\circ} \mathrm{C}$, year, and the interactions of both variables with laying date were modeled as covariates and the dataset as a fixed factor (with dataset $\mathrm{AB}$ as reference). Year was also modeled as a random effect on the intercept 

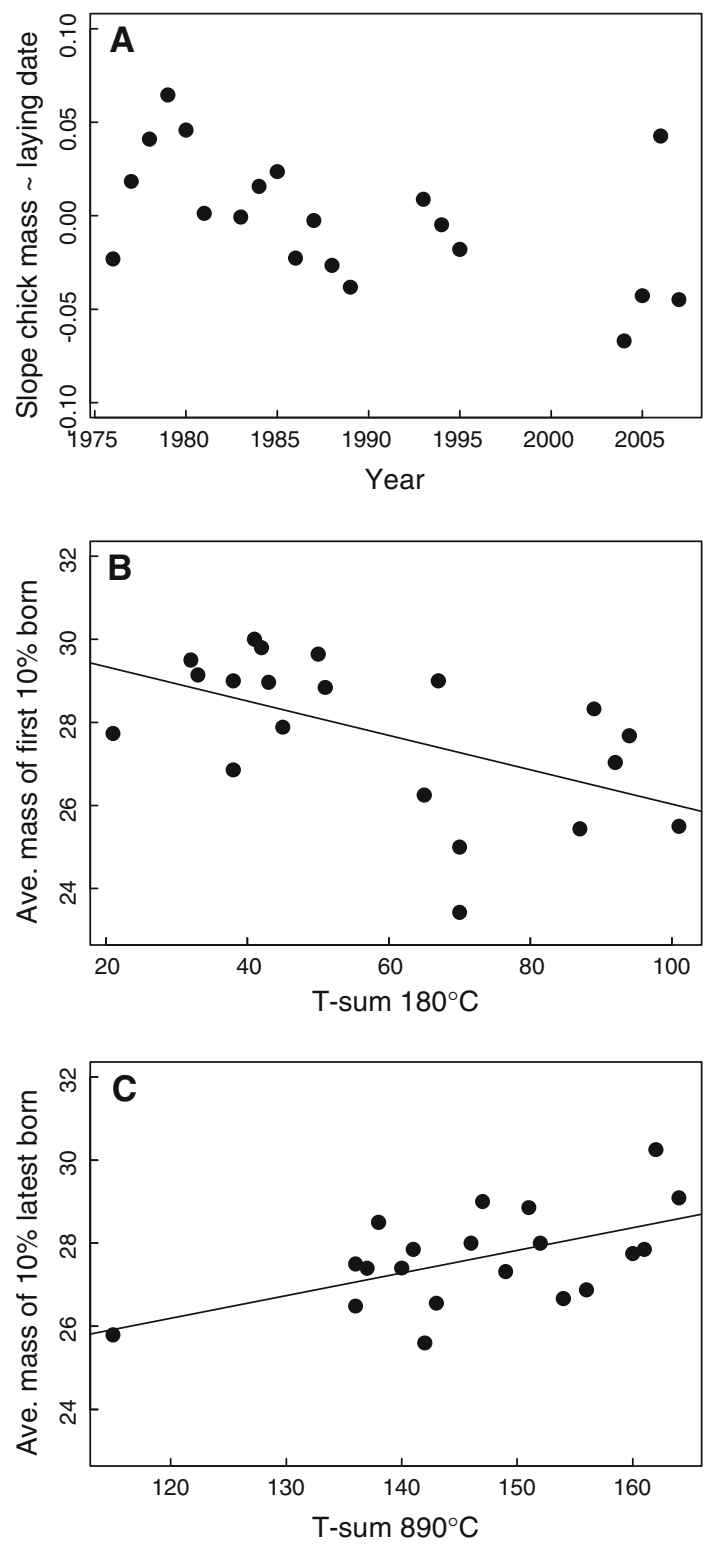

Fig. 5 a Parameter estimates of the slope of single regressions per year, modeling hatchling mass of Black-tailed Godwits in The Netherlands in relation to laying date. b Average hatchling mass (g) of the first (b) and last (c) $10 \%$ of Black-tailed Godwits born annually in relation to the date when the temperature-sum of $180^{\circ} \mathrm{C}$ was reached

development may well have led to higher food stocks for adult Black-tailed Godwits following their arrival to their breeding grounds (Beintema et al. 1985). Before 1976, Godwits had advanced laying dates by approximately 14 days, but the results of our study and those of Kleijn et al. (2010) demonstrate that laying date has not advanced any further since 1976. This lack of advancement in laying date contrasts with those observed in other waders (Both et al. 2005) and the general effect of temperature on laying date in other bird species (Dunn 2004).
Since 1976, agricultural change has continued and spring temperatures have kept on rising; consequently, the penalty of breeding late has most likely also increased. Therefore, an effective conservation of Godwits can only be established if we know why they have not continued to adjust reproductive timing. Are Godwits constrained to lay earlier, or is it not beneficial because the benefits do not outweigh the costs? Interestingly, Godwits have not been completely inert in terms of their reproductive behavior to changes in their environment: with rising late winter temperatures, they lay larger eggs early in the season and smaller eggs later. In this section, we explore possible reasons for this lack of laying date adjustment, the potential adaptive value of the change in egg size over the breeding season, and whether this knowledge can be used to improve conservation measures for this rapidly declining bird species.

In general, birds' breeding dates are ultimately determined by the timing of food availability for chicks and the costs for parents to lay their eggs at a certain time (Drent 2006). Godwit chicks forage on insects from the grass canopy, and adults, especially in early spring, rely on soil invertebrates. Knowledge of the timings of peak availability of these different food sources, and hence the selection pressures on breeding date, is important if we are to understand why Godwits decline so rapidly and how this may be halted. Without (early) mowing, insects are mostly available during the second half of May and early June (in the years 1993-1995; probably earlier at the present time), but the first grass cut starts at the end of April, and the median mowing dates in recent years have been around 10 May (Schekkerman and Beintema 2007; Kleijn et al. 2010). Mowing results in a steep drop in insect availability and decreased shelter for the chicks (Schekkerman and Beintema 2007). At the beginning of the 20th century, mowing never started before 10 June (Beintema et al. 1985); this has advanced gradually to the current time at the end of April (Beintema et al. 1985; Kleijn et al. 2010). This change in mowing date has altered the fitness of the landscape in terms of the breeding time in Godwits: in recent years, earlyhatched Godwits have a threefold higher survival than lateborn chicks (Roodbergen and Klok 2008). Godwits take on average 27 days from the start of egg-laying to hatching, and chicks need to forage in the grass canopy for at least 24 days before fledging. Thus, Godwits should start egglaying at least 51 days before mowing, which at present means that in intensively managed grasslands they should lay before 20 March. In reserves managed for breeding meadowbirds, mowing is often delayed until 15 June. Consequently, in these areas, the observed laying date in mid-April is just early enough to raise chicks before mowing. However, fledging success for late chicks is likely to be impaired here as well (see below). 
Godwits have not advanced their laying date since the mid 1970s, and the question is whether this lack of advance could be explained by constraints in the food sources for adults during laying? Here, we present suggestive evidence both in favor and against the food constraint hypothesis. Due to increased drainage and higher spring temperatures, soils warm up earlier, thereby enhancing the activity and growth of soil invertebrates on which adult Godwits forage. Our observation that in warmer years early Godwits have increased their egg mass suggests that in those years they are better able to accumulate resources, resulting in larger eggs being laid. It is an open question whether they could have used these resources also for laying earlier, and how much earlier this could have been. Furthermore, later laying individuals did not increase egg size, but rather decreased it. We suggest that this could also be explained by the change in agricultural practices: a consequence of low water tables, the widespread installation of drainage pipes, and the leveling of fields would be top soils drying out more quickly. This drying-out would lead to a rapid decline in the accessibility to soil invertebrates during the course of a warm spring season, negatively affecting the nutritional status of late-laying females and their egg size. However, the correlation between laying date and March rainfall can also be interpreted as suggesting a food constraint on earlier laying: improved drainage makes food for adults before laying less accessible, but less so in wet years.

The changes described above for intensively managed areas apply to a lesser extent to meadowbird reserves. Here, mowing is later and drainage is normally absent, but the water tables sometimes are still low because these are managed at larger spatial scales. Most of our reproductive data come from such specially managed areas where the penalty for laying late may have increased less steeply than in intensively managed grasslands. The absence of a laying date advancement could therefore be partly due to selection for extensively managed habitats. The lack of advancing laying date could thus result from food constraints during egg laying, but alternatives do exist. Plasticity in laying dates to changing circumstances may be limited (Nussey et al. 2005; Charmantier et al. 2008); the observed advance during the last century may be what was maximally possible given the genetic and/or physiological make-up of the species and selection pressures imposed by other life-cycle stages. For migrating passerines, for example, it has been argued that adjustment of laying date to climate change is constrained by an inflexible annual cycle (Both and Visser 2001). For conservation practice, it is essential to know whether such limits exist; if they do, investment in creating ideal conditions on the breeding grounds would be ineffective, and areas without fields mown later than 15 June cannot be made suitable for Godwits.
Massive reproductive losses through early mowing are prevented in areas with special management for meadowbirds, but here also Black-tailed Godwits have generally declined, albeit less dramatically than in intensive agricultural meadows (van Egmond and de Koeier 2006). Several hypotheses exist for this decreasing trend, such as increased predation losses, too low ground water, or losses by emigration to surrounding areas that act as ecological traps. An alternative hypothesis is that despite delayed mowing in reserves, the timing of the birds' breeding season has become out of synchrony with the period that most insects are available as diet for chicks (see also Kleijn et al. 2010). Insect abundance is often strongly determined by temperature and the flowering time of their food plants, and ongoing climate change may result in advancing insect life-cycles (Pearce-Higgins et al. 2009). Moreover, the harvestability of those insects by wader chicks is also heavily influenced by vegetation density, which has increased through an advance in vegetation growth, due to increased temperature, that equates to a 'virtual delay' of chick hatching dates by 2-3 weeks (Kleijn et al. 2010).

The lack of further advancement in laying date thus also leads to meadowbird reserves becoming less effective because the birds nowadays breed too late to exploit their full potential. Postponing not only mowing dates but also vegetation development to create an accessible sward with a high availability of invertebrates for chicks is therefore paramount to the successful conservation of Black-tailed Godwits in both agricultural grasslands and reserves. This can be achieved in agricultural land more than in reserves by reducing fertilizer input, although this measure could jeopardize the availability of soil invertebrates for adults. Maintaining or restoring high water tables does not have this drawback and may improve breeding conditions for Godwits through multiple pathways. If drainage indeed constrains food availability for adult Godwits in the prelaying period, measures aimed at higher water tables will lead to a more suitable habitat for chicks and, in addition, may enable a further advancement of laying date.

Acknowledgments We thank It Fryske Gea, Fûgelwacht Warkum, Petra de Goeij, Valentijn van den Brink, and Freek Mandema for invaluable help in the field, and Theo Claassen and Henk Westerhof for historical data on water tables. This work was done under the license number DEC 4112B following the Dutch Animal Welfare Act Article 9. It was financially supported by a set-up grant to TP from the University of Groningen, a grant to JS from the Schure-BeijerinckPopping Foundation, and a grant by the Vogelbescherming Nederland. PL was supported by a grant from the Portuguese Science Foundation.

Open Access This article is distributed under the terms of the Creative Commons Attribution Noncommercial License which permits any noncommercial use, distribution, and reproduction in any medium, provided the original author(s) and source are credited. 


\section{References}

Amat JA, Fraga RM, Arroyo GM (2001) Variations in body condition and egg characteristics of female Kentish plovers Charadrius alexandrinus. Ardea 89:293-299

Baayen R (2007) Analyzing linguistic data: a practical introduction to statistics using R. Cambridge University Press, Cambridge

Beintema A (1995) Fledging success of wader chicks, estimated from ringing. Ringing Migration 16:129-139

Beintema AJ, Beintema-Hietbrink RJ, Müskens GJDM (1985) A shift in the timing of breeding in meadow birds. Ardea 73:83-89

Bolton M, Houston D, Monaghan P (1992) Nutritional constraints on egg formation in the lesser black-backed gull: an experimental study. J Anim Ecol 61:521-532

Both C, Visser ME (2001) Adjustment to climate change is constrained by arrival date in a long-distance migrant bird. Nature 411:296-298

Both C, Visser ME (2005) The effect of climate change on the correlation between avian life history traits. Glob Change Biol 11:1606-1613

Both C, Artemyev AV, Blaauw B, Cowie R, Dekhuizen H et al (2004) Large-scale geographical variation confirms that climate change causes birds to lay earlier. Proc R Soc Lond B 271:1657-1662

Both C, Piersma T, Roodbergen S (2005) Climate change explains much of the 20th century advance in laying date of northern lapwing Vanellus vanellus in The Netherlands. Ardea 93:79-88

Both C, Bouwhuis S, Lessells CM, Visser ME (2006) Climate change and population declines in a long distance migratory bird. Nature 441:81-83

Both C, van Asch M, Bijlsma R, van den Burg A, Visser ME (2009) Climate change and unequal phenological changes across four trophic levels: constraints or adaptations. J Anim Ecol 78:73-83

Chamberlain D, Fuller RJ, Bunce R, Duckworth J, Shrubb M (2000) Changes in the abundance of farmland birds in relation to the timing of agricultural intensification in England and Wales. J Appl Ecol 37:771-788

Charmantier A, McCleery RH, Cole LR, Perrins CM, Kruuk LEB, Sheldon BC (2008) Adaptive phenotypic plasticity in response to climate change in a wild bird population. Science 320:800-803

Claassen T (2008) Historisch overzicht van het peilbeheer van de friese boezem in relatie to ecosystem- en waterkwaliteit. Twirre 19:74-83

Daan S, Tinbergen JM (1997) Adaptation in life histories. In: Krebs JR, Davies NB (eds) Behavioural ecology: an evolutionary approach. Blackwell, Oxford, pp 311-333

Drent R (2006) The timing of birds' breeding seasons: the Perrins hypothesis revised especially for migrants. Ardea 94:305-322

Dunn P (2004) Breeding dates and reproductive performance. Adv Ecol Res 35:69-87

Edwards C, Lofty J (1982) Nitrogenous fertilizers and earthworm populations in agricultural soils. Soil Biol Biochem 14:515-521

Gill JA, Langston, RHW, Alves JA, Atkinson PW, Bocher P et al (2007) Contrasting trends in two black-tailed godwit populations: a review of causes and recommendations. Wader Study Group Bull 114:43-50

Groen N, Hemerik L (2002) Reproductive success and survival of black-tailed godwits Limosa limosa in a declining local population in The Netherlands. Ardea 90:239-248

Haverschmidt F (1963) The black-tailed godwit. Brill, Leiden

Kleijn D, Schekkerman H, Dimmers WJ, van Kats RJM, Melman TCP, Teunissen WA (2010) Adverse effects of agricultural intensification and climate change on breeding habitat quality of black-tailed godwit Limosa l. limosa in the Netherlands. Ibis 152:475-486
Kruk M, Noordervliet MAW, ter Keurs WJ (1996) Hatching dates of waders and mowing dates in intensively exploited grassland areas in different years. Biol Cons 77:213-218

Monaghan P, Nager RG, Houston DC (1998) The price of eggs: increased investment in egg production reduces the offspring rearing capacity of parents. Proc R Soc Lond B 265:1731-1735

Nager RG (2006) The challenges of making eggs. Ardea 94:323-346

Nussey DH, Postma E, Gienapp P, Visser ME (2005) Selection on heritable phenotypic plasticity in a wild bird population. Science 310:304-306

Pearce-Higgins JW, Gill JA (2010) Unravelling the mechanisms linking climate change, agriculture and avian population declines. Ibis 152:439-442

Pearce-Higgins JW, Yalden DW (2004) Habitat selection, diet, arthropod availability and growth of a moorland wader: the ecology of European golden plover Pluvialis apricaria chicks. Ibis 146:335-346

Pearce-Higgins JW, Dennis P, Whittingham MJ, Yalden DW (2009) Impacts of climate on prey abundance account for fluctuations in a population of a northern wader at the southern edge of its range. Glob Change Biol 16:12-23

R Development Core Team (2009) R: a language and environment for statistical computing. R Foundation for Statistical Computing, Vienna

Roodbergen M, Klok C (2008) Timing of breeding and reproductive output in two black-tailed godwit Limosa limosa populations in The Netherlands. Ardea 96:219-232

Roodbergen M, Klok C, Schekkerman H (2008) The ongoing decline of the breeding population of black-tailed godwits Limosa l. limosa in The Netherlands is not explained by changes in adult survival. Ardea 96:207-218

Schekkerman H, Beintema AJ (2007) Abundance of invertebrates and foraging success of black-tailed godwit Limosa limosa chicks in relation to agricultural grassland management. Ardea 95:39-54

Schekkerman H, Boele A (2009) Foraging in precocial chicks of the black-tailed godwit Limosa limosa: vulnerability to weather and prey size. J Avian Biol 40:369-379

Schekkerman H, Müskens GJDM (2000) Do black-tailed godwits Limosa limosa breeding in agricultural grasslands produce sufficient young for a stable population? Limosa 73:121-134

Schekkerman H, Teunissen W, Oosterveld E (2009) Mortality of black-tailed godwit Limosa limosa and northern lapwing Vanellus vanellus chicks in wet grasslands: influence of predation and agriculture. J Ornithol 150:133-145

Schroeder J, Lourenço PM, Hooijmeijer JCEW, Both C, Piersma T (2009) A possible case of contemporary selection leading to a decrease in sexual plumage dimorphism in a grassland-breeding shorebird. Behav Ecol 20:797-807

Schroeder J et al (2010) Linking intronic polymorphism on the CHD1-Z gene with fitness correlates in black-tailed godwits Limosa l. limosa. Ibis 152:368-377

Tryjanowski P, Sparks T (2001) Is the detection of the first arrival date of migrating birds influenced by population size? A case study of the red-backed shrike Lanius collurio. Int J Biomet 45:217-219

van Egmond P, de Koeier T (2006) Weidevogelbeheer bij agrariërs en terreinbeheerders. De Levende Natuur 107:118-120

Visser ME, Lessells CM (2001) The costs of egg production and incubation in great tits (Parus major). Proc R Soc Lond B 268:1271-1277

Williams TD (2005) Mechanisms underlying the costs of egg production. Bioscience 55:39-48

Zuur A, Ieno E, Elphick C (2010) A protocol for data exploration to avoid common statistical problems. Methods Ecol Evol 1:3-14 